\title{
TINJAUAN KETERDAPATAN EMAS PADA KOMPLEKS OFIOLIT DI INDONESIA
}

\author{
Oleh: \\ Teuku Ishlah \\ Pusat Sumber Daya Geologi \\ Jl. Soekarno Hatta No. 444 Bandung
}

\begin{abstract}
SARI
Indonesia memiliki beberapa komplek ofiolit seperti yang ditemukan di Pegunungan Bobaris dan Pegunungan Meratus di Kalimantan Selatan, Tanah Grogot Kalimantan Timur, Bombana di Sulawesi Tenggara, dan Pegunungan Cycloops di Papua. Di Kawasan kompleks ofiolit tersebut banyak ditemukan mineralisasi yang muncul setempat-setempat dan secara terbatas ditemukan emas. Hal ini kemungkinan berkaitan dengan mineralisasi emas yang berasosiasi dengan komplek ofiolit. Mineralisasi emas dalam ultrabasa masih belum diketahui secara luas karena belum dikaji secara intensif. Di beberapa area komplek ofiolit di Indonesia pernah menjadi area Kontrak Karya Pertambangan Umum, sehingga data mineralisasi yang berkaitan dengan ofiolit sangat berguna sebagai bahan kajian agar dapat diperoleh penerapan model mineralisasi. Tinjauan ini dimaksudkan untuk mendapatkan gambaran mineralisasi pada lingkungan komplek ofiolit di Indonesia.
\end{abstract}

Kata kunci : mineralisasi, emas, ofiolit, ultrabasa

\begin{abstract}
Indonesia has several ophiolite complexes such as Bobaris and Meratus Mountains in South Kalimantan, Tanah Grogot in East Kalimantan, Bombana in Southeast Sulawesi, and Cycloops Mountains in Papua. In these complexes, mineralization locally occurs and gold as well. It posibbly related to ophiolite-associated gold mineralization. Mineralization in Indonesia ophiolite complex has not been understood since it has not been assessed intensively. Several Contract of Work used to be exist in these ophiolite complexes, therefore mineralization data gained from these areas become useful for assesment to get aplicable mineralization model. This review is aimed to get overview of ophiolite-associated gold mineralization in Indonesia.
\end{abstract}

Keywords : mineralization, gold, ophiolite, ultramafic 


\section{PENDAHULUAN}

Pembentukan ofiolit telah lama menjadi perdebatan para ahli geologi. Sejak berkembangnya teori tektonik lempeng, pemahaman mengenai ofiolit menjadi semakin mudah dipahami. Ofiolit dikenal juga sebagai batu ular karena mirip dengan warna dan tekstur kulit ular. Sampai saat ini kebanyakan ahli geologi percaya bahwa batuan ofiolit merupakan fragmen dari kerak samudera yang terbentuk pada pematang tengah samudera (mid-oceanic ridge) dan bermigrasi ke zona subduksi di dalam sabuk lipatan batas benua oleh proses tumbukan dari lempeng litosfer sehingga terbentuk secara alokton (allochtonous nature). Ofiolit tersingkap secara luas di sepanjang lajur yang mengalami tektonisme kuat (Coleman, 1977). Pada umumnya ofiolit muncul pada barisan pegunungan hasil tumbukan (collisional mountain range), merupakan kumpulan dari endapan laut dalam, basalt, gabro dan batuan ultrabasa yang terbentuk dari kerak samudera dan terangkat ke dalam kerak benua oleh proses yang dikenal sebagai subduksi. Menurut Monnier dkk (1999), runtunan ofiolit mulai dari urutan bawah ke atas (Gambar 1)

Alas batuan malihan (metamorphic sole) terbentuk di atas mélange dalam runtunan ideal dikenal juga sebagai batuan malihan sub-ofiolit. Kumpulan batuan malihan yang lengkap biasanya menunjukkan pengurangan derajat metamorfisme yang cenderung semakin menurun tajam dari fasies granulit sampai sekis hijau. Selubung Utama (primary mantle) dengan litologi berupa lerzolite yang merupakan magma dari selubung mantel.

Satuan Tektonit Ultrabasa, terdiri dari batuan ultramafik harzburgit, Iherzolit, kromit dunit, dan piroksenit. Sebagian besar ofiolit disusun oleh batuan harzburgite yang miskin akan unsur aluminium. Namun pada beberapa komplek ofiolit lainnya seperti Iherzolite merupakan tipe batuan peridotit yang dominan. Dunit pada umumnya hadir sebagai lensa di dalam harzburgite atau Iherzolit. Piroksenit terbentuk sebagai

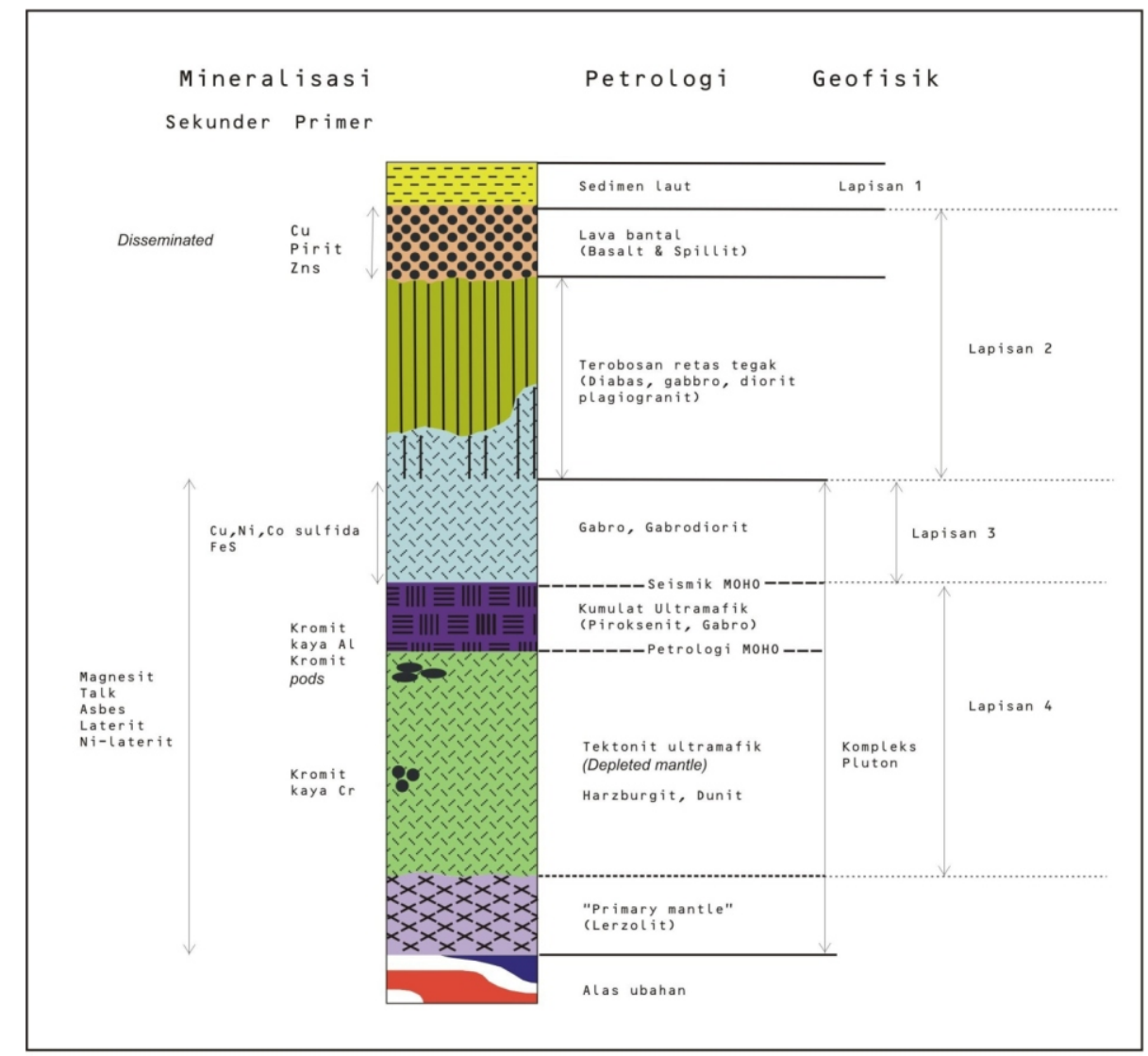

Gambar 1. Kolom Runtunan Ofiolit Lengkap Menurut Moores (1982),Wilson (1992) 
lapisan, lensa atau retas di dalam harzburgite atau Iherzolit yang terlipat dan arahnya sejajar dengan arah perlipatan atau memotongnya seperti arah retas.

Satuan kumulat Ultrabasa dihasilkan oleh proses kristalisasi fraksional magma basa. Diawali dengan batuan dunit dan kromitit yang diikuti diatasnya oleh interlayer wherlit, olivin piroksenit dan piroksenit, berangsur menjadi batuan gabroik yang kaya dengan mineral plagioklas. Satuan ini diperkirakan berada tidak selaras diatas zona tektonit ultrabasa. Bagian dasar pada umumnya didominasi oleh fabric laminar dari olivin berkaitan dengan pertumbuhan dan pengendapan kristal kumulat. Satuan ini juga merupakan batas petrologi Moho, sementara batas seismik Moho berada pada batas atas.

Satuan Gabro - Gabrodiorit, merupakan bagian atas dari seksi kumulat ultrabasa, biasanya ditempati oleh sekuen batuan mafik sampai leukokratik (leucocratic). Karakter tekstur unit ini diindikasikan oleh mineral amfibol dan plagioklas yang sangat kasar sampai halus.

Satuan Terobosan Retas Tegak, juga dikenal sebagai sheeted dykes complex yang tegak lurus dengan satuan batuan yang menutupi di atasnya. Karena tidak semua komplek ofiolit memiliki satuan batuan terobosan retas tegak ini, beberapa menunjukkan terdapat satuan batuan ekstrusi yang menumpuk secara langsung di atas batuan pluton.

Satuan Lava Bantal, ke atas dari komplek ini terbentuk sequen regular horizontal dari lava masif, lava bantal, breksi dan tuff.

Satuan Sedimen Laut, yaitu suatu sekuen sedimen yang menunjukkan lingkungan antara abisal sampai batial diindikasikan oleh tipe endapan sedimenter berupa rijang-radiolaria, batugamping pelagik merah, endapan mengandung logam besi (metaliferous) merah-kuning dan breksi vulkanik.

Mineralisasi mineral logam dan mineral bukan logam dalam urutan di atas, terdiri dari mineral logam kromit, dan mineral logam sulfida seperti nikel, tembaga dan seng. Mineralisasi logam sulfida dalam lingkungan ofiolit ini juga ditemukan di beberapa tempat di Indonesia seperti di Bobaris Kalimantan Selatan. Sedangkan mineral bukan logam mungkin berbentuk magnesit, talk dan asbes. Mineralisasi emas tidak dijelaskan dalam urutan tersebut diatas. Namun mineralisasi emas dalam lingkungan ofiolit ditemukan di berbagai tempat di tanah air.

\section{TINJAUAN UMUM EMAS DI DAERAH OFIOLIT}

Mineralisasi emas dalam komplek ofiolit telah lama diperbincangkan dan dipertanyakan oleh para ahli geologi. Buisson dan Leblanc (1986) menyatakan bahwa mineralisasi emas dalam batuan ultrabasa bisa ditemukan pada jalur Archean Greenstone Belt. Dalam batuan ultrabasa tersebut ditemukan mineral ubahan antara lain ubahan karbonat (carbonate alteration), metasomatisme kalium-natrium (K-Na metasomatism), gerusan dan mineralisasi sulfida (shearing and sulphide mineralization). Fenomena alterasi dan mineralisasi yang sama dapat ditemui dalam komplek ofiolit dengan keterjadian emas pada batuan ultrabasa yang terkarbonatisasi.

Ahli Geologi Uni Sovyet melakukan penelitian di Pegunungan Alpen pada batuan ultrabasa yang mengalami ubahan karbonasisasi menjadi batuan karbonat yang disebut liswanit. Pada umumnya batuan karbonat tersebut terbentuk dari Mg$\mathrm{Fe}-\mathrm{Ca}$ karbonat, dan kuarsa yang berasosiasi dengan serpentin, talk, Mgklorit, fuchsite (Cr-muscovite), dan mineral bijih logam seperti hematit, magnetit, sulfida $\mathrm{Fe}-\mathrm{Ni}$ atau Fe-Cu dan sisa krom - spinel. Lensa liswanit umumnya terletak di sepanjang kontak tektonik dan zona batuan karbonat-talk dalam ultrabasa terserpentinisasi. Untuk menyusun model mineralisasi emas liswanit (genetic model for gold-bearing liswanites). Buisson dan Leblanc (1986) menyelidiki endapan emas di Komplek Ofiolit Liguaria di Italia, komplek ultrabasa di paparan Saudi Arabia, dan Ophiolit Bou Azzer di Maroko Afrika Utara.

Dari mineralisasi emas yang terdapat pada batuan ultrabasa di Komplek Ofiolit Liguaria di Italia, komplek ultrabasa di paparan Saudi Arabia, dan Ophiolit Bou Azzer di Maroko Afrika Utara, diketahui bahwa sebaran mineralisasi emas sangat acak dalam batuan ubahan liswanit berbentuk lensa. Sebagian besar dari hasil 
analisis dari percontohan batuan memperlihatkan ciri yang sama yakni mengandung emas antara 0,02 sampai dengan 0,1 ppm. Kadar emas pada batuan liswanit menunjukkan pengayaan antara 5 sampai dengan 20 kali dari harga kandungan emas rata-rata dalam batuan ultrabasa (2 $10 \mathrm{ppb})$. Demikian juga hasil dari contoh batuan samping liswanit, memperlihatkan hubungan positif antara unsur emas dengan arsen. Selain As, unsur $\mathrm{Ba}, \mathrm{Sb}, \mathrm{B}, \mathrm{Bi}, \mathrm{Ag}, \mathrm{Cu}$ juga berasosiasi dengan kadar emas tinggi sehingga dapat digunakan untuk petunjuk zona mineralisasi.

Konsentrasi emas dalam liswanit berhubungan dengan sulfida dan arsen yang diangkut oleh sisa larutan hidrotermal yang mengandung belerang. Lensa liswanit terbentuk pada tahap akhir dari kegiatan tektonik berupa serpentinisasi batuan peridotit mantel, yang merupakan bagian dari sekuen batuan ofiolit.

Dari hasil kajian dari ketiga lokasi mineralisasi emas tersebut diatas, Buisson dan Leblanc (1986) mengusulkan genetic model for gold-bearing listwaenites (Gambar 2) yang menjelaskan bahwa ;

Liswanit adalah batuan karbonat dalam ultrabasa dari ofiolit yang merupakan areal sasaran eksplorasi emas. Genesa mineralisasi emas dan mineral ubahan yang terjadi serupa dengan yang ditemukan pada batuan karbonatit di jalur ultrabasa berumur Archean.
Sumber utama emas yang berasosiasi dengan mineral sulfida, kromit, magnetit adalah batuan ultrabasa yang terserpentinisasi. Kadar emas ekonomis terdapat pada urat kuarsa yang mengandung pirit, kadar unsur arsen yang tinggi.

Model genetik mineralisasi emas liswanit dalam sekala besar berupa sistem hidrotermal terjadi pada akhir dari tectonic emplacement dan serpentinisasi dari ultrabasa, Au diperkaya oleh mineral opak dan diangkut dalam larutan thio-arsenic $\left(\mathrm{CO}_{2}-\mathrm{S}-\mathrm{As}-\mathrm{Cl}-\mathrm{Na}-\mathrm{K}-\mathrm{B}\right)$ yang berhubungan dengan proses serpentinisasi. Kontak tektonik berperan sebagai saluran dari larutan hidrotermal dalam proses karbonatisasi.

\section{KETERDAPATAN EMAS PADA BEBERAPA KOMPLEK OFIOLIT DI INDONESIA}

\section{Komplek Ofiolit Meratus}

Pegunungan Meratus dan Bobaris, terletak di Kalimantan Selatan dan memanjang ke arah utara hingga Kalimantan Timur. Batuan ofiolit MeratusBobaris termasuk tipe dari Komplek ofiolit yang lengkap menurut sekuen ofiolit ideal. Sabuk ofiolit ini berlanjut kearah barat daya menembus Jawa bagian tengah (Karang Sambung) dan memiliki hubungan dengan batuan ultrabasa yang berada di pulau

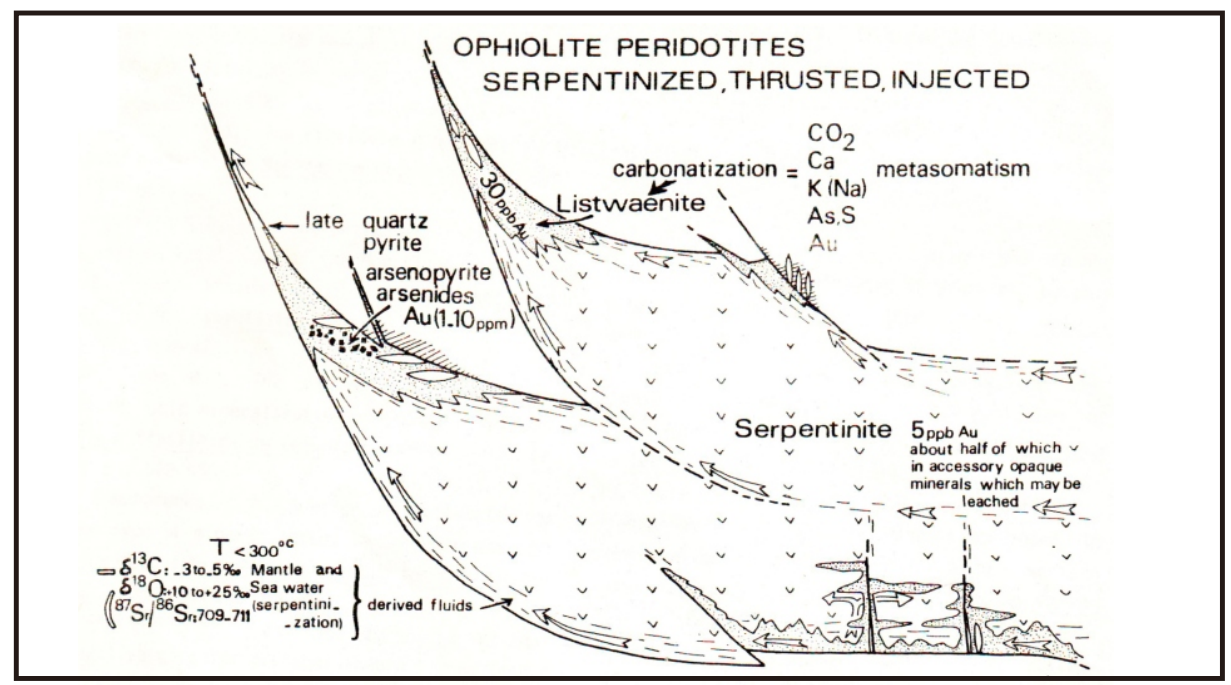

Gambar 2. Model genetik mineralisasi emas dalam kompleks ofiolit 
Sumatera. Di Pulau Laut yang ditempati oleh peridotit dan satuan gabro secara tidak selaras ditutupi oleh konglomerat. Batuan peridotit diterobos oleh batuan gabro dan diorit dalam bentuk retas. Batuan sedimen yang tersingkap di Pegunungan Meratus terdiri dari Formasi Alino yang tersusun dari seri batuan vulkaniklastik berupa aliran lava, intrusi, breksi vulkanik graywackes dan tufa; Komplek Ofiolit yang tersusun oleh harzburgite, piroksenit, werlit, websterit, dunit, gabro, dan gabrodiorit. Secara setempat batuan ultrabasa mengalami serpentinisasi. Alas ubahan dari batuan ultrabasa diatas berupa sekis kristalin. Satuan ini memiliki hubungan sesar naik (overthrust) di atas Formasi Alino; dan Formasi Manunggal yang tersusun oleh batuan vulkanogenik, yang diendapkan setelah terjadinya anjakan ofiolit. Batuan ofiolit dan Formasi Manunggal diterobos oleh korok basal, andesitik, dan sejumlah intrusi gabroik, dioritik dan granitik (Gambar 3).
Berdasarkan hasil kompilasi dan pengamatan di lapangan, di pegunungan Bobaris dan pegunungan Meratus bayak terdapat indikasi mineralisasi emas yang terkait dengan batuan ofiolit yang diantaranya tersebar di Kabupaten Banjar, Tanah Laut, Banjarbaru dan Kotabaru. Sebagian besar berupa endapan letakan (placer) di Pamali, Riam Kanan, Sungai Besar, Sungai Kalaan, Sungai Tambanio berupa endapan kuarter yang berasosiasi dengan batuan terobosan basa - ultrabasa berupa dunit teralterasi dan peridotit.

Di dusun Kembatang Kecil, Buluh Kuning, Kotabaru Kalimantan Selatan, ditempati peridotit dan dunit yang diterobos oleh retas gabro/diabas (Gambar 4). Kuarsa felspar porfiri, secara tektonik menempati bagian timur dari satuan batuan ultrabasa sedangkan felspar porfiri berada di di bagian selatan Kembatang Kecil. Batuan ultrabasa tersebut telah tersilisifikasi, karbonatisasi, terbreksikan dengan urat-urat kuarsa yang

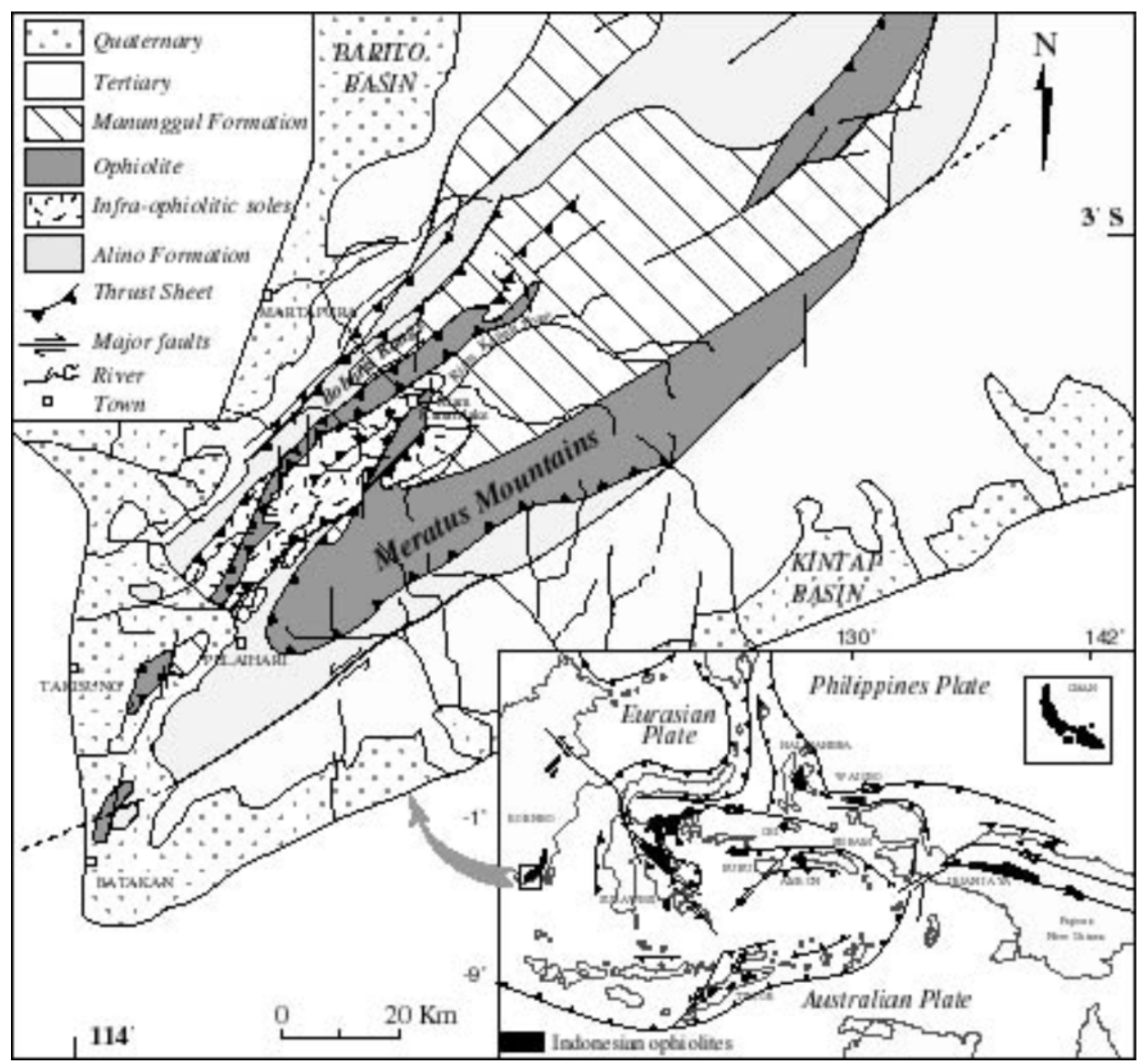

Gambar 3. Geodinamika Kalimantan Bagian Tenggara (Priyomarsono, 1984 dalam Monnier,1999) 


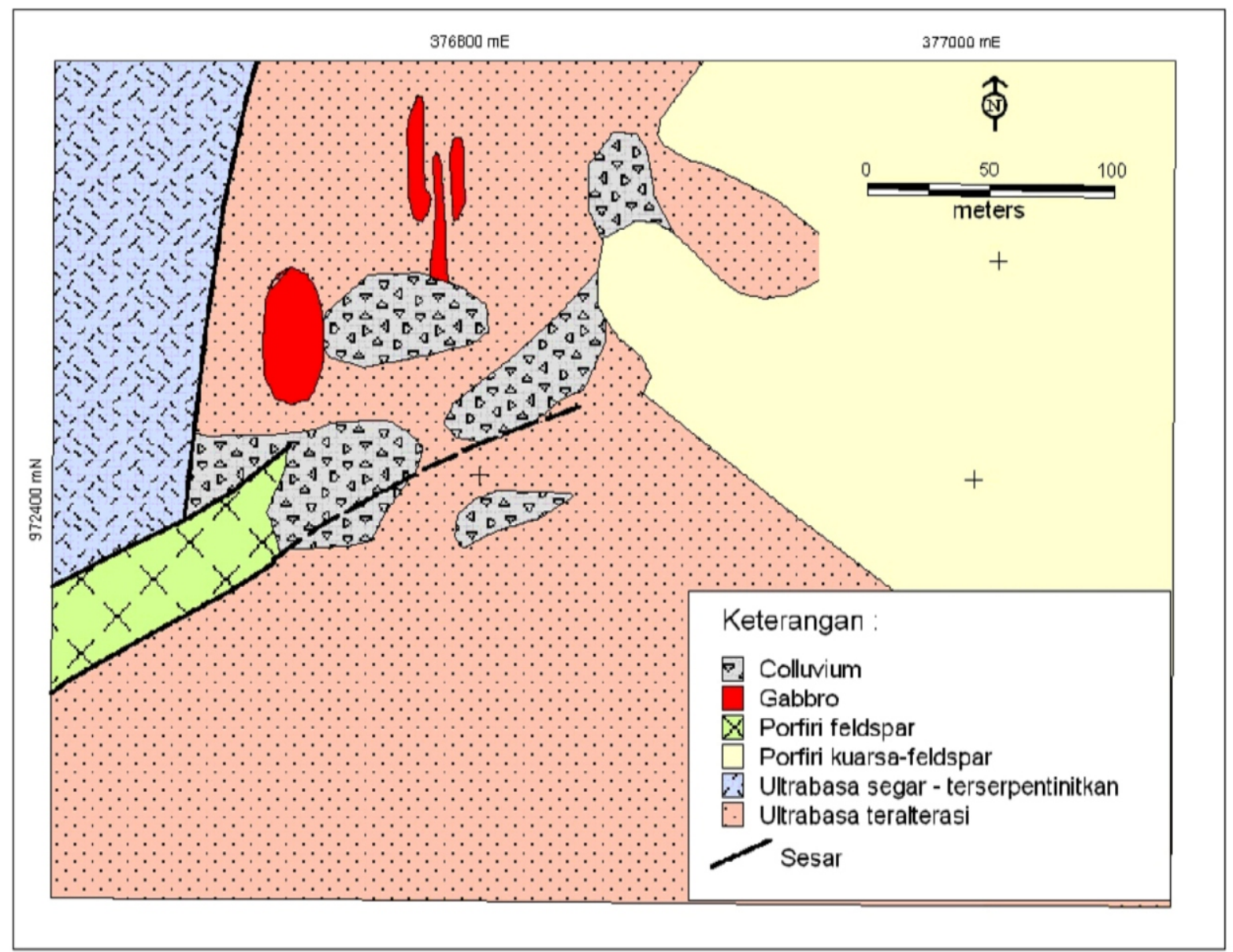

Gambar 4. Peta Geologi Kembatang Kecil, Kabupaten Tanah Bumbu Kalimantan Selatan (PT Meratus Sumber Mas, 1995)

membentuk stockwork. Mineralisasi emas muncul pada batuan ultrabasa yang teralterasi, pada dyke diabas dan pada kontak kuarsa felsfar porfiri dengan batuan ultrabasa yang teralterasi. Mineralisasi emas juga muncul dalam urat-urat kuarsa dan pada dinding dalam felspar porfiri. Di bagian barat, terdapat batuan ultrabasa yang terserpentinisasi sebagai batuan dasar dan kontak sesar dengan batuan gabro/diabase (batuan terobosan). Di bagian timur tersusun oleh kuarsa felspar porfiri yang mengalami mineralisasi dengann ubahan serpertinisasi, talk, propilitik, silisifikasi, dan phyllic dan mineralisasi emas dengan kadar Au 1,32 4,23 gr/t ( PT Meratus Sumber Mas, 1995).

Di Miing, Teluk Kepayang, Kotabaru, ditemukan mineralisasi emas dan tembaga yang berasosiasi dengan pirit dan kalkopirit, kadar Au antara 0,1-17,26 gr/t, dan Cu antara 03 - 0,72 gr/t. Daerah Sampanahan menempati bagian tengah dari Pegunungan
Meratus, yang terbentuk oleh penyusupan lempeng dan tumbukan busur kontinen pada zaman kapur yang ditempati oleh peridotit, piroksenit, harzburgit, dunit dan gabbro. Serpentinisasi yang kuat muncul dekat struktur-struktur regional dan tubuh-tubuh batuan terobosan. Dalam skala regional, seluruh batuan diatas diterobos oleh oleh batuan yang berkomposisi diorit-granit yang muncul sebagai kolom-kolom dan retasretas memanjang yang berhubungan erat dengan struktur regional, berumur berumur Kapur Muda atau Tersier Awal. (PT Scorpion Sampanahan, 2001).

Di Gunung Melati, Kecamatan Panyipatan, Kabupaten Tanah Laut, Kalimantan Selatan, ditemukan emas berasosisi dengan peridotit terserpentinkan, gabro, sekis talk klorit, sekis mafic, diorit diterobos andesit porfiritik dengan mineralisasi emas dalam bentuk urat kuarsa. Sumberdaya tereka diperkirakan 
mencapai 377.500 ton dengan kadar Au 2,5 $4 \mathrm{gr} / \mathrm{t}$. Selain itu, di daerah mineralissi emas, di daerah Gunung Melati juga ditemukan anomali unsur platinum $(\mathrm{Pt})$ dengan kadar diatas 0,1 ppm dengan panjang zona anomali mencapai $1,5 \mathrm{~km}$. Hal ini diperoleh berdasarkan hasil analisis contoh tanah dari bor tangan (hand auger) pada kedalaman antara 0 - 4 meter. Anomali platinum terdapat dalam laterit hasil pelapukan batuan serpentinisasi. Bila unsur platinum berkadar lebih dari 0,1 ppm diperbandingkan dengan unsur $\mathrm{Pd}$, diperoleh rasio $1: 1,2$. Ini menunjukkan bahwa anomali platinum merupakan hasil dari pengkayaan supergen yang terbatas pada laterit pelapukan ultrabasa. Unsur emas dalam laterit ini dilaporkan sangat rendah (Third Relinquishment Report for The Pelaihari Contract of Work Area November, 1991).

\section{Bombana}

Secara administratif, Bombana berada wilayah Kabupaten Bombana, Provinsi Sulawesi Tenggara. Daerah penyelidikan meliputi Kecamatan Poleang Utara, Kecamatan Rarowatu dan Kecamatan Rarowatu Utara, Kabupaten Bombana Provinsi Sulawesi Tenggara (Gambar 5). Secara tektonik terletak di selatan sabuk Ofiolit Sulawesi Timur.

Hasil penyelidikan Pusat Sumber Daya
Geologi (2010) menunjukkan bahwa emas primer terdapat pada satuan batuan sekis yang mengalami pemineralan berupa uraturat kuarsa yang mengisi rekahan atau rongga-rongga penjajaran (foliasi) mineral pada satuan batuan sekis, sehingga mengubah batuan menjadi tersilisifikasi. Mineral-mineral kuarsa yang mengisi rekahan atau rongga-rongga membentuk struktur cockade, vuggy dan dog teeth (Gambar 6).

Secara regional, Bombana terletak disebelah selatan Sabuk Ofiolit Sulawesi Timur tersusun oleh batuan basa, ultrabasa, batuan sedimen pelagik, dan melange pada beberapa tempat. Batuan ultrabasa mendominasi pada lengan tenggara pulau Sulawesi, sementara batuan basa dominan pada bagian utara terutama sepanjang pantai utara dari lengan timur. Runtunan batuan ofiolit lengkap ditemukan pada lengan timur yang terdiri dari batuan ultrabasa, basa, lava bantal dan sedimen pelagik yang didominasi oleh batugamping laut dalam dan interkalasi rijang berlapis. Sabuk Ofiolit ini sudah mulai terbentuk selama tumbukan jaman Kapur. Kolisi pada jaman Neogen terjadi antara benua mikro Banggai-Sula, Tukangbesi-Buton dan Mekongga dengan sabuk metamorf Sulawesi bagian tengah dan Sabuk Ofiolit Sulawesi Timur, dimana lempeng mikro

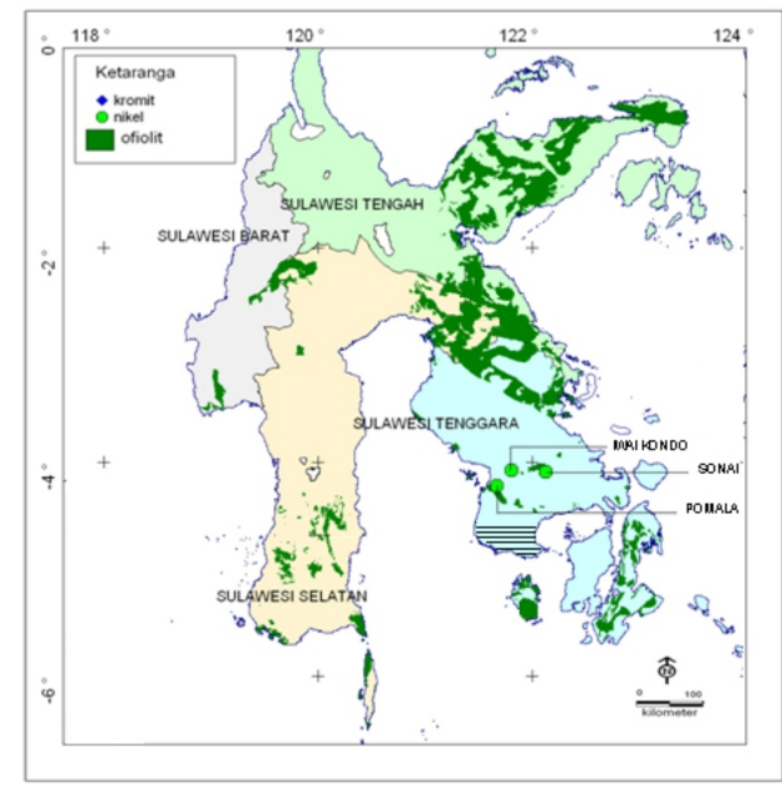

Gambar 5. Peta Sebaran Ofiolit pulau Sulawesi dan lokasi keterdapatan mineralisasi emas di Bombana, Sulawesi Tenggara 


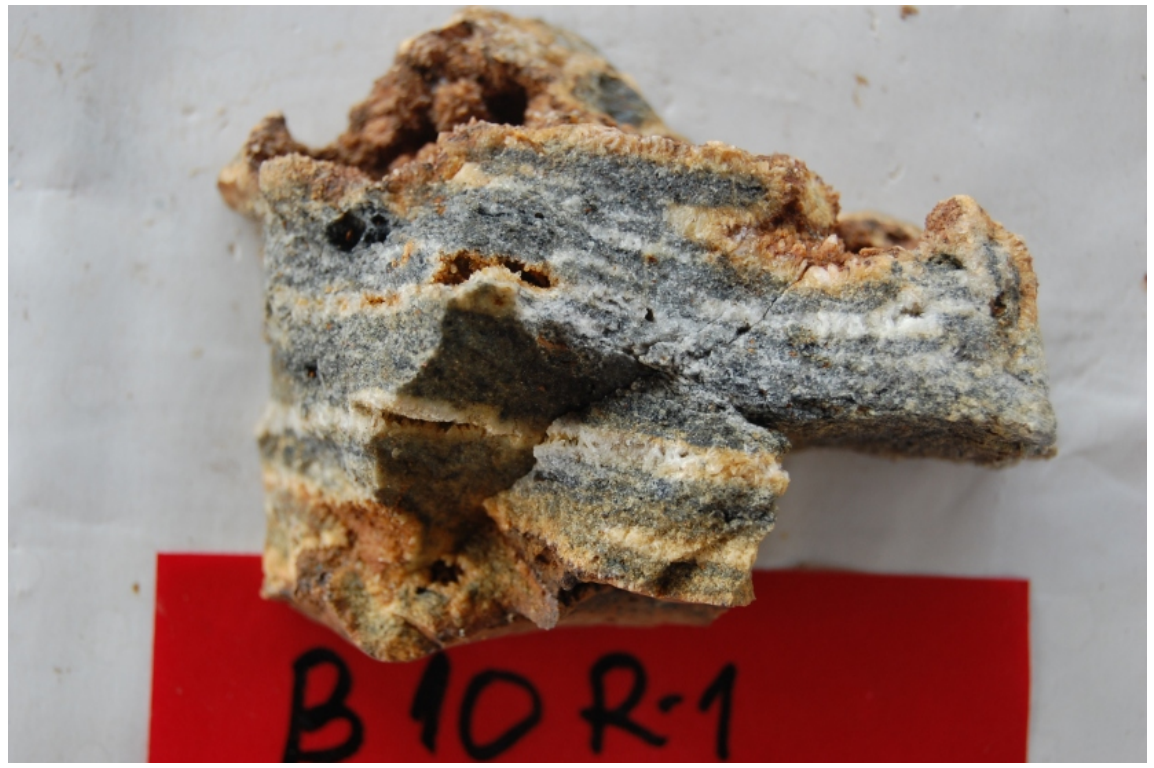

Gambar 6. Contoh batuan batuan sekis yang mengalami tersilifikasi kuat (Laporan Tahunan Pusat Sumber Daya Geologi 2010)

benua menyusup dibawah sabuk ofiolit dan daerah tumbukan (batuan dasar metamorf). Di sabuk Timur Sulawesi, batuan ofiolit ini sangat penting dalam pengembangan industri pertambangan, dengan terdapat Tambang Nikel Soroako. Antara Bombana dan Sabuk ini terdapat singkapan batuan ultrabasa yang merupakan bagian dari dari sabuk Timur Sulawesi seperti Tambang Pomala yang merupakan lokasi penambangan Ferronikel. Dari posisi geografis dan umur, maka sekis yang mengandung emas di Bombana, penulis perkirakan bahwa sekis tersebut merupakan batuan dasar dari ofiolit Sulawesi Timur.

\section{Sentani Jayapura}

Secara geologi, Daerah Danau sentani terletak dalam komplek Cycloops yang tersusun oleh batuan Kelompok Malihan Cycloops, Satuan Batuan Ultramafik, Satuan Batuan Mafik, Formasi Auwewa, Formasi Nubai, Formasi Makats, Formasi Aurumi, Formasi Unk, Formasi Jayapura, Endapan Kipas Aluvial dan Endapan Aluvial. Struktur geologi antiklin, sinklin, sesar normal, sesar naik dan sesar mendatar. Arah umum struktur regional pada batuan sedimen berarah baratlaut tenggara, beberapa hampir mendekati barat baratlaut, timur tenggara dan utara baratlaut, selatan tenggara terutama pada batuan Tersier. Struktur timurlaut - barat baratdaya terdapat pada batuan malihan dan ultrabasa, sedangkan yang hampir utara selatan pada batugamping Kuarter dan juga batuan malihan. Di sekitar Sentani ditemukan pertambangan emas tanpa izin di Bumi Perkemahan dan Koya Koso. PETI di Bumi Perkemahan terdapat di dalam endapan koluvialberukuran pasir - kerakal, bagian atas didominasi lempung - pasir halus, berketebalan $3 \mathrm{~m}$ hingga lebih dari $10 \mathrm{~m}$, mengandung fragmen kuarsa yang melimpah $(20 \%)$ serta fragmen batuan ultramafik (5\%), metamorfik (5\%) dan urat kuarsa $(10 \%)$ dengan kadar emas sekunder sebesar $45 \mathrm{mgr} / \mathrm{m}^{3}$. Di jalan raya menuju lokasi PETI Bumi Perkemahan dijumpai singkapan endapan talk yang berbentuk lensa kecil atau urat (?) dalam batuan sekis, dan terlihat jelas berada disekitar kontak dengan batuan ultramafik. PETI di Koya Koso terdapat di dalam endapan koluvial berwarna kelabu kemerahan, berukuran lempung - bongkah, berketebalan $1-4 \mathrm{~m}$, mengandung fragmen batuan ultramafik (5 $\%)$, metamorfik (5\%), batugamping (3\%) dan urat kuarsa $(5 \%), 7,5 \mathrm{mgr} / \mathrm{m}^{3}$.

\section{Desa Kebutuh Duwur}

Di desa Kebutuh Duwur, Kabupaten banjar negara ditemukan penambangan emas tanpa izin. Butiran emas ditemukan pada batuan ultrabasa (dunit) yang telah 


\section{MAKALAH ILMIAH}

terubah/alterasi dengan minral ubahan terdiri serpentinisasi dan karbonatisasi dapat diamati pada batuan ultrabasa, yang ditrobos urat kuarsa pirit, arsenopirit dan malakit (Widodo, dkk., 1999). Pada saat ditinjau ke lokasi PETI Kebutuh Duwur, ditambang pada batuan ultrabasa ditemukan urat-urat kuarsa dan karbonat yang disertai mineral bijih pirit

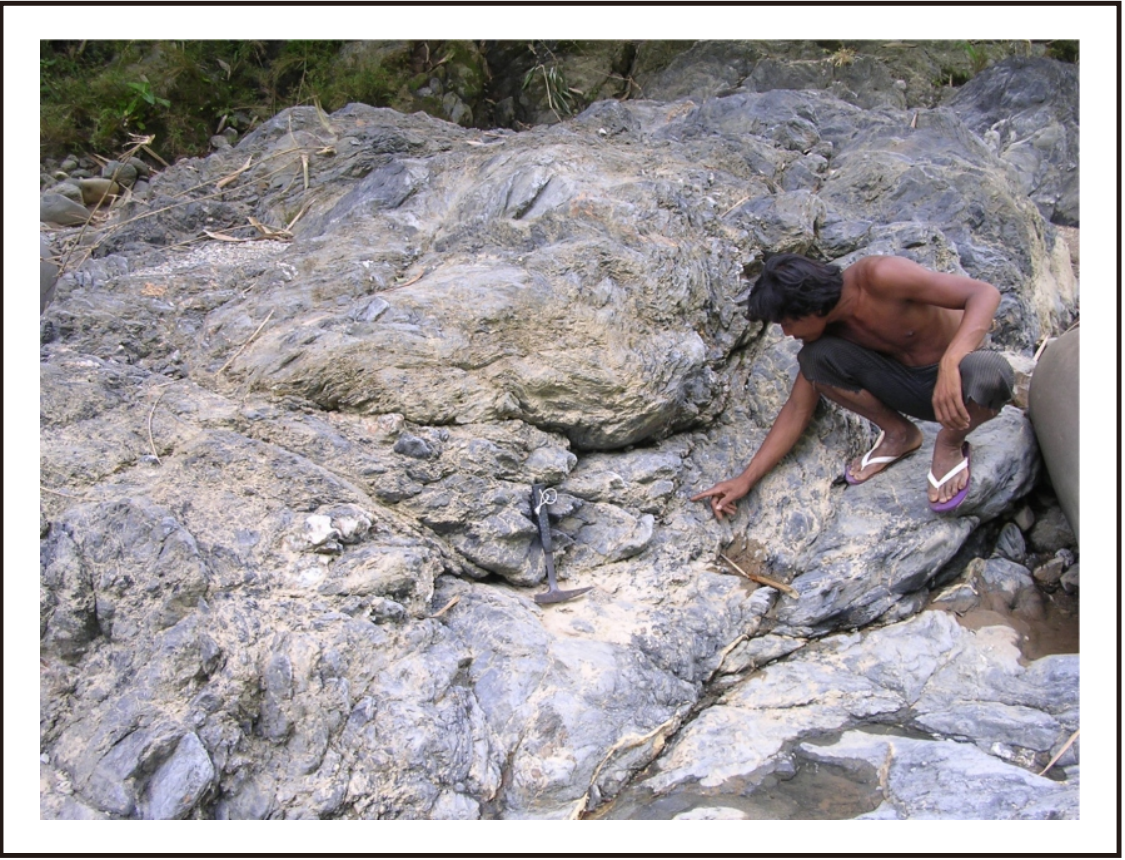

Gambar 7. Urat karbonat dan urat kuarsa pada batuan ultrabasa di Kebutuh Duwur

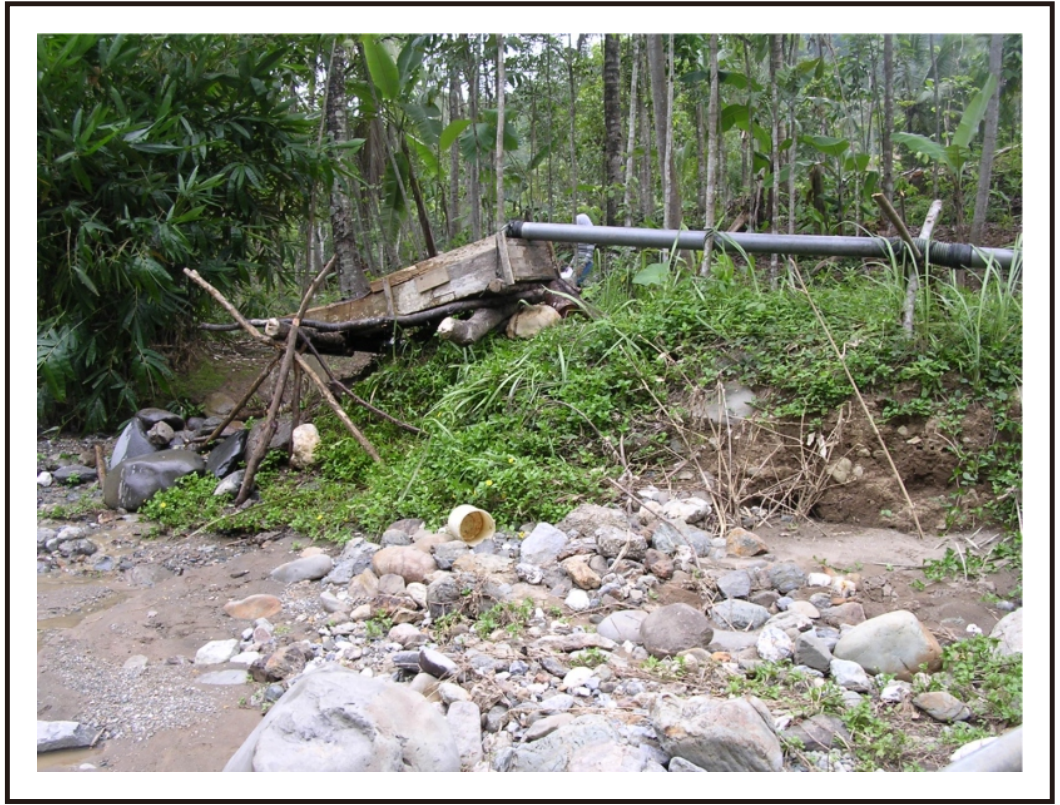

Gambar 8. Foto kegiatan pendulangan oleh masyarakat di Kebutuh Duwur 


\section{PENUTUP}

Hasil tinjauan Komplek ofiolit di Indonesia seperti di pegunungan Meratus, Sulawesi Timur dan Papua, atas terdapatnya penambangan emas tanpa izin dan hasil eksplorasi emas di daerah tersebut, sukar untuk diterapkan model genetik dengan tepat karena data dukung data sangat minim terutama data tentang batuan ubahan karbonatit (liswanit) yang mengandung emas. Namun dengan pendekatan model tersebut, diketahui bahwa mineralisasi emas dalam batuan ofiolit di Indonesia sangat menarik untuk dibahas. Kemungkinan ditemukan endapan emas dalam Komplek ofiolit juga mungkin pada masa depan. Untuk Pegunungan Meratus dan Bobaris yang merupakan sabuk Komplek ofiolit lengkap seperti pada sekuen ofiolit, ditemukan mineralisasi emas. Mineralisasi emas di Pegunungan Meratus, berkaitan dengan terobosan batuan yang lebih muda. Sambungan sabuk ini ke arah barat daya hingga di Jawa Tengah terdapat mineralisasi emas yang berasosiasi dengan ubahan karbonatit. Di Daerah Papua, banyak ditemukan emas dalam batuan ofiolit. dari seluruh areal ofiolit yang terdapat indikasi emas, umumnya berada pada jalur tektonik yang kuat dalam bentuk patahan, sesar naik, kekar dan bidang penjajaran sehingga larutan sisa dapat memasukinya.

Dari penjelasan diatas, ada kemungkinan mineralisasi emas di dalam Komplek ofiolit di Indonesia berkaitan dengan mineralisasi karbonatit yang mrupakan pembawa mineralisasi emas. Untuk itu diperlukan evaluasi kembali daerah mineralisasi emas dalam Komplek ofiolit di Indonesia karena dalam wilayah tersebut banyak ditemukan endapan emas baik dari PETI maupun dari KK Pertambangan umum dalam rangka pemahaman mineralisasi emas dalam Komplek ofiolit.

\section{UCAPAN TERIMA KASIH}

Ucapan terima kasih disampaikan buat rekan-rekan Pusat Sumber Daya Geologi yang telah membantu dan memberikan masukan dalam menyelesaikan makalah ini.

\section{DAFTAR PUSTAKA}

Anonim, 2010. Laporan Tahunan Inventarisasi, Penyelidikan dan Konservasi Sumber Daya Geologi 2009, publikasi Pusat Sumber Daya Geologi 2009.

Anonim, 2001. Laporan Eksplorasi untuk Kontrak Karya Kode Wilayah 99 PK 0150, Kalimantan Selatan, PT Scorpion Sampanahan Mineral, 2001.

Anonim, 1995. Report on First Year of Feasibility Study Period. PT Meratus Sumber Mas, 1995 (tidak dipublikasikan)

Anonim,1991. Third Relinquishment Report for The Pelaihari Contract of Work Area, PT Pelaihari Mas Utama, 1991

Buisson $\mathrm{G}$ and Leblanc M, 1986. Gold bearing listwanit (carbonatized ultramafic rocks) from ophiolite complex, Ophiolite Confrence, Glasgow, England.

Coleman Robert G., 1977. Ophiolites, Ancient Oceanic Litosphere?, Springer-Verlag Berlin Heidelberg New York.

Monnier C., Plolve M., Pubellier M., Maury R.C., Bellon H and Permana H., 1999. Extensional to Compressive at the SE Eurasian Margins as Record from the Meratus Ophiolite (Borneo, Indonesia), Geodinamica Acta, 12, 4355. 